Federal Reserve Bank of New York

Staff Reports

\title{
CDS and Equity Market Reactions to Stock Issuances in the U.S. Financial Industry: Evidence from the 2002-13 Period
}

\author{
Marcia Millon Cornett \\ Hamid Mehran \\ Kevin Pan \\ Minh Phan \\ Chenyang Wei
}

Staff Report No. 697

November 2014

Revised December 2014

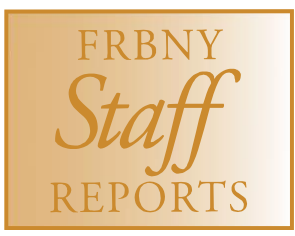

This paper presents preliminary findings and is being distributed to economists and other interested readers solely to stimulate discussion and elicit comments. The views expressed in this paper are those of the authors and do not necessarily reflect the position of the Federal Reserve Bank of New York or the Federal Reserve System. Any errors or omissions are the responsibility of the authors. 


\title{
CDS and Equity Market Reactions to Stock Issuances in the U.S. Financial Industry: Evidence from the 2002-13 Period
}

Marcia Millon Cornett, Hamid Mehran, Kevin Pan, Minh Phan, and Chenyang Wei

Federal Reserve Bank of New York Staff Reports, no. 697

November 2014; revised December 2014

JEL classification: G01, G21, G32

\begin{abstract}
We study seasoned equity issuances by financial and nonfinancial companies between 2002 and 2013. To assess the risk and valuation implications of these issuances, we conduct an event-study analysis using daily credit default swap (CDS) and stock market pricing data. The major findings of the paper are that equity prices do not react to new issues in the pre-crisis period, but react negatively in the crisis. CDS prices respond to new, default-relevant information. Over the full sample period, cumulative abnormal CDS spreads drop in response to equity issuance announcements. The reactions are significantly stronger during the financial crisis when the federal government injected equity into financial institutions to ensure their viability. The market reacted to this by assessing significantly lower costs for default protection via credit default swaps on equity issue announcements. The evidence indicates that single-name CDS based on financial firms' default probabilities are potentially useful for private investors and regulators.
\end{abstract}

Key words: financial institutions, stock issuance, credit default swaps, financial crisis

Cornett: Bentley University (e-mail: mcornett@bentley.edu). Mehran: Federal Reserve Bank of New York (e-mail: hamid.mehran @ ny.frb.org). Pan: Harvard University (e-mail: kevinpan@fas.harvard.edu). Phan: Federal Reserve Bank of New York (e-mail: minh.phan@ny.frb.org). Wei: American International Group (e-mail: chenyang.wei@aig.com). The authors are grateful to Viral Acharya, Malcolm Baker, Patrick Bolton, Atul Gupta, Otgo Erhemjamts, Mark Flannery, Charles Kahn, Jim Musumeci, Stewart Myers, Anjan Thakor, and seminar participants at Bentley University for their helpful comments. The views expressed in this paper are those of the authors and do not necessarily reflect the position of the Federal Reserve Bank of New York or the Federal Reserve System. 


\section{CDS and Equity Market Reactions to Stock Issuances in the U.S. Financial Industry: Evidence from the 2002 - 2013 Period}

\section{Introduction}

Financial theory and empirical analysis has shown that, because security values are determined by the distribution of the market value of a firm's assets, market prices of different securities issued by a firm are closely linked. Specifically, market prices of financial securities issued by firms should reflect the default risk of the firms. Less explored is the relation between market prices of various credit related securities for the same firm. For example, the link between the relatively new, but fast growing credit derivatives market and equity markets has only begun to be explored. ${ }^{1}$ One such market is the single name credit default swap (CDS) market. A single name CDS is a contract that provides protection against a default event involving a single issuer, or 'name.' Therefore, single name CDS contracts should reflect the pure issuer default risk of a firm irrespective of any issue specific risk. Thus, single name CDS contracts are of particular interest in that they may serve as a benchmark for measuring and pricing credit risk of a firm.

CDS prices arguably are related to the health of financial institutions. Banks are required to maintain adequate capital due to regulatory requirements. While the market and regulators may have assessed that banks were adequately capitalized prior to 2008, the perception changed with the failure of Bear Stearns. In addition to TARP capital infusions during the crisis, banks in effect were forced to issue large amounts of equity capital (and forgo payouts) to manage their risk, thus establishing a viable business model (and also to payback the TARP funds). As a result, the reaction of CDS prices to equity issuances may be different before versus during the crisis. The effect of equity issuances in turn may be related to whether or not banks could use the proceeds for

\footnotetext{
${ }^{1}$ For example, Norden and Weber (2009) analyze the relationship between credit default swap (CDS), bond, and stock markets between 2000 and 2002. Focusing on the intertemporal co-movement, they find that stock returns lead CDS and bond spread changes. Further, they find that the CDS market is more sensitive to the stock market than the bond market and the strength of the co-movement increases the lower the credit quality and the larger the bond issues.
} 
asset funding and/or maintaining their capital needs. Practitioners recognize that while equity issuances can help with asset funding, the issues typically are much more important for solvency (which supports asset funding on a larger scale). ${ }^{2}$ Figure 1 shows the shows the empirical distribution of the Tier 1 capital gap for 39 bank equity issuances during the sample period. The Tier 1 gap is calculated as the difference between the financial firm's Tier 1 risk-based capital ratio the quarter before the equity issue announcement and the FDIC benchmark of 6\% required to be classified as a well-capitalized institution. ${ }^{3}$ A negative Tier 1 gap means that the institution's Tier 1 capital ratio falls below that threshold. In the quarter before announcing an equity issuance, 21 of the 39 banks have a Tier 1 capital ratio below 6\%. Thus, it is always true that equity issuances directly help reduce funding pressure by the amount raised, and often true that they help improve funding capability indirectly by improving solvency.

In this paper, we study equity and CDS market reactions to 129 seasoned equity issuances that were announced by 56 financial companies between 2002 and 2013. For a baseline comparison, we examine similar announcement returns for 356 issues by 172 nonfinancial firms over the same period. We do this as the purpose behind equity issuance by financials may be different than nonfinancials; for example, as stated earlier, to address capital requirements as opposed to funding needs. The perception of capital needs changed over the sample period due to adoption of new capital requirement(s) and market assessment of implication no bailout policy

\footnotetext{
${ }^{2}$ Mehran and Thakor (2011) address the question of whether there is an optimal capital structure for each bank, and if so, what this implies about how bank capital and value are related in the cross-section within the context of bank mergers and acquisitions. The main result of their model is that there is an optimal capital structure for each bank, and in the cross-section of banks, value is increasing in capital. This is counter to what is popularly believed: that bank value is decreasing in capital. In fact, bank capital positively affects total bank value. The results are both statistically and economically significant. Proposition 1 establishes that banks that keep higher equity capital monitor more. The intuition is clear: a bank that keeps more equity faces a lower probability of being closed and hence a higher probability of retaining its relationship banking rents, which are increasing in monitoring. Proposition 2 shows that while the marginal benefit of equity identified in Proposition 1 is the same for all banks, the marginal cost of equity is not, so equity is less attractive to banks with higher marginal cost of equity. This finding has the important implication that banks choose to keep capital voluntarily (i.e., in the absence of capital requirements).

${ }^{3}$ See https://www.fdic.gov/regulations/laws/rules/2000-4500.html.
} 
regime under Dodd-Frank legislation. As a result, financial firms raised fresh capital through new equity issuances. To better understand the purpose behind the issuances, we split the sample period, analyzing market reactions before versus during the financial crisis. We take a unique approach to measuring a change in the market's perception of the probability of firm default. We collect and analyze CDS data to assess the risk and valuation implications of these seasoned equity issuances. We focus on financial institutions because they were heavily involved in, and some would argue at the center of, the financial crisis. Further, unlike any other industry, financial institutions were required to increase capital during and after the crisis. Thus, this industry represents a unique opportunity to examine the relation between single name CDS securities and equity securities issued by the firms.

Consistent with previous empirical findings, we find that the stock market generally reacts negatively to announcements of common stock issuances by financial firms: the three-day cumulative abnormal stock returns (CARs) average $-1.43 \%$ percent over the sample period. We also find that reactions are more negative during the financial crisis, albeit not significantly so: the average CARs range from $-1.58 \%$ to $-2.02 \%$ during the sample period (although announcement returns are insignificant in the pre-crisis period). Stock market reactions to equity issuances by nonfinancials have a similar pattern to that reported in earlier research, i.e., negative and significant throughout the sample period (the overall reaction is a loss of $2.87 \%$ ). The pre-crisis CARs for nonfinancial firms with single name CDS securities traded is in the order $1.10 \%$ to $1.77 \%$, while crisis period CAR is about $3.8 \%$. Nonfinancial equity issuers face larger losses during crisis than financials.

We also find that CDS prices respond quickly to new default-relevant information. Over the full sample period, cumulative abnormal CDS spreads (CAS) drop significantly (by an average 
of $10.12 \mathrm{bps}$ ) in response to equity issuance announcements by financial firms. However, the results are due to crisis period events only. The mean CASs is significant in the crisis period (ranging from -16.15 bps to $-18.84 \mathrm{bps}$ ), but is insignificant for pre-crisis events. These patterns are not found for nonfinancial firms that issue equity over the same period, the overall effect is insignificant (although CAS is negative and significant (ranging from -3.26 to $-4.80 \mathrm{bps}$ ) in the pre-crisis period). Cross-sectional analysis suggests that riskiness of the institution is one of the key determinants of both abnormal stock returns and abnormal CDS spreads. Equity issuances by riskier institutions (rated speculative grade) are received more favorably in the CDS market and by stock investors. However, the relations fail to hold during the financial crisis.

During the financial crisis, the federal government injected equity (through the TARP program) into financial institutions. The equity was made senior to common stock, but not to other capital providers. Thus, the market reacted to this by assessing lower costs for default protection via credit default swaps and insignificant changes in returns on equity issue announcements. Further, creditors obtained an additional buffer against losses in the event of default. As a result, the certification effect of an equity issue announcement prior to the financial crisis was not necessarily the dominant effect during the crisis. During the financial crisis, issuances of equity by higher risk financial firms did not provide the same degree of default-relevant information as they did before the crisis. Thus, the evidence indicates that single named CDSs based on financial firms' default probabilities are potentially useful for private investors and regulators.

The remainder of the paper is organized as follows. Section 2 summarizes recent research on CDS contracts as measures of default risk. Section 3 describes the data and methodology used in the analysis. Section 4 discusses the results. Finally, Section 5 concludes the paper. 


\section{CDS contracts as a measure of default risk}

In this paper, we take a unique approach to measuring a change in the market's perception of the probability of a debt default. Specifically, we collect and analyze single name credit default swap data. In the event of a default, the CDS writer compensates the CDS buyer for losses on a given face value of the underlying debt. The spread on the CDS contract is the price paid to the writer of the CDS for selling this insurance contract to the CDS buyer. When the market perceives that the probability of a debt default decreases (increases), the spread charged on the CDS decreases (increases). Thus, we use changes in the CDS spread to measure changes in the market's perception of the probability of a debt default.

Several papers have examined the ability of CDS spreads to measure risk. Hull et al. (2004) explore the extent to which credit rating announcements by Moody's are anticipated by participants in the credit default swap market. They conclude that either credit spread changes or credit spread levels provide helpful information in estimating the probability of negative credit rating changes. Jorion and Zhang (2007) examine the intra-industry information transfer effect of Chapter 11 bankruptcies, Chapter 7 bankruptcies, and jump events, as captured in the credit default swaps (CDS) and stock markets. They find strong evidence of contagion effects (positive correlations across CDS spreads) for Chapter 11 bankruptcies and competition effects (negative correlations across CDS spreads) for Chapter 7 bankruptcies. They also find that a large unanticipated jump in a company's CDS spread leads to the strongest evidence of credit contagion across the industry. Ismailescu and Kazemi (2010) examine the effect of sovereign credit rating change announcements on the CDS spreads of the event countries, and their spillover effects on other emerging economies' CDS premiums. They find that positive events have a greater impact on CDS markets in the two-day period surrounding the event, and are more likely to spill over to 
other emerging countries. Alternatively, CDS markets anticipate negative events, and previous changes in CDS premiums can be used to estimate the probability of a negative credit event.

Most recently, papers have focused on CDS spread movements around the financial crises in the U.S. and Europe. For example, Fontana and Scheicher (2010) study the relative pricing of euro area sovereign CDS and the underlying government bonds for ten euro area countries from January 2006 to June 2010. They find that, since September 2008, CDS spreads have on average exceeded bond spreads, which may have been due to 'flight to liquidity' effects and limits to arbitrage. Arce et al. (2012) analyze the extent to which prices in the sovereign CDS and bond markets reflect the same information on credit risk in the context of the European Monetary Union. They find that there are persistent deviations between both spreads during the crisis. Levels of counterparty and global risk, funding costs, market liquidity, volume of debt purchases by the European Central Bank in the secondary market, and the banks' willingness to accept losses on their holdings of Greek bonds are found to be significant factors in determining which market leads price discovery. Andenmatten and Brill (2011) test whether the co-movement of sovereign debt CDS premia increased significantly after the Greek debt crisis started in October 2009. Their results indicate that during the Greek debt crisis there were not only periods of interdependence, but also periods characterized by a significant increase in the co-movement of sovereign credit risk as measured in CDS premia.

Di Cesare and Guazzarotti (2010) examine the determinants of credit default swap spread changes for a large sample of U.S. nonfinancial companies from January 2002 and March 2009. They use variables that have previously been found to have an impact on CDS spreads. Since the onset of the crisis, they find that CDS spreads have become much more sensitive to the level of leverage, while volatility has lost its importance. They also show that since the beginning of the 
crisis CDS spread changes have been increasingly driven by a common factor, which cannot be explained by indicators of economic activity, uncertainty, and risk aversion. Alexopoulou et al. (2009) confirm the existence of a long-run relationship between CDS and corporate bond markets, and the tendency for CDS markets to lead corporate bond markets in terms of price discovery. They find that the outbreak of the financial crisis induced a substantial increase in risk aversion and a shift in the pricing of credit risk, with CDS markets becoming more sensitive to systematic risk, while bond markets priced in more information about liquidity and idiosyncratic risk. Moreover, the crisis also brought about a systematic disconnection between the two markets caused by the significant change in the lead-lag relationship, with CDS markets always leading bond markets. Finally, Galil et al. (2014) use a cross-sectional analysis to investigate the determinants of CDS spreads around the financial crisis. Fundamental variables such as historical stock returns, historical stock volatility, and leverage explain CDS spreads after controlling for ratings. During the crisis, while fundamental variables maintained their explanatory power, the explanatory power of ratings decreased to almost zero.

A few recent studies have focused on single name CDS spreads for financial firms. For example, Kallestrup et al. (2012) show that financial linkages across borders are priced in the CDS markets beyond what can be explained by exposure to common factors. They construct a measure which takes into account the relative size and riskiness of bank exposures to domestic government bonds and other domestic residents. This measure helps explain the dynamics of bank CDS premia after controlling for country specific and global risk factors. Demirguc-Kunt et al. (2010) investigate the impact of government indebtedness and deficits on bank stock prices and CDS spreads for a sample of international banks. They find that the change in bank CDS spreads in 2008 relative to 2007 reflects countries' deterioration of public deficits. Ballester et al. (2013) use 
bank CDS spreads to evaluate contagion among banks and banking sectors in different countries during the financial crisis. They find the Eurozone troubles barely affected U.S. banks. De Bruyckere et al. (2013) use correlations in CDS spreads at the bank and at the sovereign level to document significant contagion between bank and sovereign credit risk during the European sovereign debt crisis. ${ }^{4}$ Possibly most relevant for our study, Flannery et al. (2010) evaluate the viability of credit default swaps (CDS) spreads as substitutes for credit ratings for large financial institutions that were prominently involved in the financial crisis. They show that CDS spreads incorporate new information about as quickly as equity prices and significantly more quickly than credit ratings.

\section{Data and methodology}

\section{3.a. Data}

The initial sample examined in this paper includes all U.S. financial institutions that issued equity between 2002 and 2013..$^{5}$ This sample is collected from S\&P's Capital IQ database. We then limit the sample to those financial firms having CDS pricing data reported by Markit. ${ }^{6}$ The final sample we examine includes data on 129 equity issuances by 56 financial institutions. ${ }^{7}$ Table 1 lists some descriptive statistics of the sample by-year: including the number of announcements, the total amount of equity issued, and the means and standard deviations of the distributions of

\footnotetext{
${ }^{4}$ Eichengreen et al. (2009) identify common factors in the movement of banks' credit default swap spreads. They find that fortunes of international banks rise and fall together even in normal times along with short-term global economic prospects. But the importance of common factors rose to exceptional levels from the outbreak of the financial crisis to past the rescue of Bear Stearns, reflecting a diffuse sense that funding and credit risk was increasing. Following the failure of Lehman Brothers, the interdependencies briefly increased to a new high, before they fell back to the preLehman elevated levels.

${ }^{5}$ The sample firms include all U.S. financial companies except for REITs, due to their distinct organizational structure.

${ }^{6}$ Markit is a private company headquartered in London. The firm provides CDS end-of-day quotes for approximately 450 of the most liquid CDS contracts, including G20 sovereigns and large financial corporations.

${ }^{7}$ Issuance transactions with public offering or shelf registration features are excluded as are non-secondary issue related transactions.
} 
relative size of the equity issuances. The table shows a fairly balanced flow in financial institutions' equity issuance activities between the first and the second half of the sample period, with the largest frequency of issues coming in 2008 and 2009. These two years also see the largest issue amounts, $\$ 90.68$ billion in 2008 and $\$ 72.08$ billion in 2009 . The vast majority of these issuances are from financial firms. Indeed, panel B of table 1 reports the mean relative issue size (dollar value of equity issuance relative to market capital) for financial firms is $24.36 \%$ in 2008 and $8.67 \%$ for nonfinancial firms: the difference is significant at better than $1 \%$. Financial firms issue significantly more relative equity than nonfinancial firms in every year during the crisis period except 2012. The Figures 1 and 2 illustrate the general movements of the CDS spreads and stock market values during the sample period. Figure 2 plots a daily series of the mean CDS spreads of our sample firms and Figure 3 plots the daily evolution of the combined equity market capitalization $^{8}$ of the sample firms. Note the significant increase in CDS spreads and decrease in financial firm values during the financial crisis.

We examine stock returns and CDS spreads for the whole sample period, as well as two sub-periods, termed in the paper, the "pre-crisis" and the "crisis" periods. We experiment with two cutoff dates to delineate the pre-crisis and crisis periods using two prominent events in 2008: 3/24/2008 (the collapse of Bear Stearns) and 10/14/2008 (the TARP Capital Purchase Program announcement). Signs of significant problems in the U.S. economy first arose in late 2006 and the first half of 2007 when home prices plummeted and defaults by subprime mortgage borrowers began to affect the mortgage lending industry as a whole, as well as other parts of the economy noticeably. As mortgage borrowers defaulted on their mortgages, financial institutions that held these mortgages and mortgage backed securities started announcing huge losses on them. A prime

\footnotetext{
${ }^{8}$ Equity market capitalization is calculated as the daily stock price times the number of shares of common stock outstanding (from CRSP data tapes).
} 
example of the losses incurred is that of Bear Stearns. In the summer of 2007, two Bear Stearns hedge funds suffered heavy losses on investments in the subprime mortgage market. The two funds filed for bankruptcy in the fall of 2007. Bear Stearns' market value was hurt badly from these losses. The losses became so great that in March 2008 J.P. Morgan Chase and the Federal Reserve stepped in to rescue the then fifth largest investment bank in the United States before it failed or was sold piecemeal to various financial institutions. On March 24, 2008, J.P. Morgan and Bear Stearns announced a merger agreement. J.P. Morgan Chase purchased Bear Stearns for \$236 million, or $\$ 2$ per share. The stock was selling for $\$ 30$ per share three days prior to the purchase and \$170 less than a year earlier. The collapse of Bear Stearns and its sale to J.P. Morgan marked the beginning of the mortgage crisis for major financial institutions. ${ }^{9}$

On October 14, 2008, then-Secretary of the Treasury Paulson announced a revision in TARP implementation in which the Treasury directly injected up to $\$ 250$ billion $^{10}$ of TARP funds (through the Capital Purchase Program (CPP)) into the U.S. banking system through the purchase of senior preferred stock and warrants in qualifying financial institutions (QFIs). ${ }^{11}$ The CPP was intended to inject equity into financial institutions that were suffering from temporary liquidity and other financial problems due to the financial crisis, but were otherwise in decent shape. By the time it closed on December 31, 2009, 707 applications were approved and funded by the Treasury through the $\mathrm{CPP}{ }^{12}$

\footnotetext{
${ }^{9}$ Using principal components analysis to identify common factors in the movement of banks' credit default swap spreads, Eichengreen et al. (2012) find that the importance of common factors rose steadily to exceptional levels from the outbreak of the Subprime Crisis to past the rescue of Bear Stearns, reflecting a diffuse sense that funding and credit risk was increasing.

10 This amount was eventually lowered to $\$ 204.9$ billion.

11 Qualifying financial institutions (QFIs) include bank holding companies, financial holding companies, insured depository institutions, and savings and loan holding companies that are established and operating in the United States and that are not controlled by a foreign bank or company.

${ }^{12}$ Cornett et al. (2013) look at how the pre-crisis health of banks is related to the probability of receiving and repaying TARP capital. They find that financial performance characteristics that are related to the probability of receiving TARP funds differ for the healthiest ("over-achiever") versus the least healthy ("under-achiever") banks. Ng et al.
} 


\section{3.b. Seasoned equity issues of nonfinancial firms}

In order to examine whether any observed relation between CDS spreads and equity market reactions is unique to financial firms, we also collect information on equity issuances by nonfinancial firms between 2002 and 2013. The initial sample of nonfinancial firm equity issuances is also collected from S\&P's Capital IQ database. We then limit the sample to those nonfinancial firms having CDS pricing data reported by Markit. The final sample of nonfinancial firms we examine includes data on 356 equity issuances by 172 firms. Table 1 lists the year-byyear distribution of the announcements.

\section{3.c. Calculation of cumulative abnormal stock returns (CARs)}

We use standard event study techniques to calculate unexpected changes in stock prices in response to equity issue announcements by the sample firms. Stock return data are collected from the Center for Research in Security Prices (CRSP) data tapes. Stock return data are identified for 54 of the 56 financial firms (123 of the 129 equity issue announcements) and 170 of the 172 nonfinancial firms (337 of the 356 events). We calculate normal stock return performance using a 125 trading day window, ending five trading days before the announcement date. A Fama-French three factor model is used to predict the expected excess return: ${ }^{13}$

$$
\text { Return }_{\text {excess }, t}=\alpha+\beta_{1}\left(\text { Market }-R_{f}\right)_{t}+\beta_{2}(S M B)_{t}+\beta_{3}(H M L)_{t}
$$

where $R_{f}$ is the risk-free return rate, $S M B$ stands for "small (market capitalization) minus big," and $H M L$ stands for "high (book-to-market ratio) minus low."

(2011) find that publicly traded TARP banks experienced significantly lower equity returns relative to non-TARP banks during TARP's initiation period. They also find that equity markets adjusted the values of the TARP banks upward in the quarters following TARP injections. Veronesi and Zingales (2010) also provide an analysis of the valuation effects of TARP, but for just the initial financial institutions that received TARP infusions on October 14, 2008. They find that, while the primary effect of TARP was to benefit bondholders, the program created little value for shareholders. While they find that valuation benefits for banks exceeded the costs imposed on taxpayers, they argue that other potential rescue strategies would have yielded larger net benefits.

${ }^{13}$ We also examined a specification where excess return is a function of the three Fama-French factors and an additional momentum factor. Results are similar to those reported in tables 3, 5, and 6 . They are available from the authors on request. 


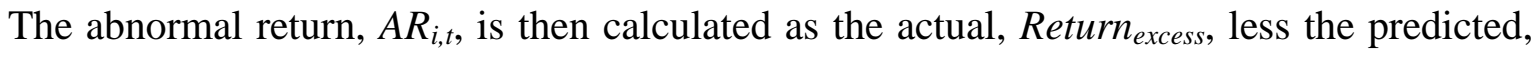
Return $_{\text {excess. }}$ Summation over the three-day window (the trading day before the announcement, the announcement day, and the following trading day) gives the three-day announcement period cumulative abnormal stock returns (CARs):

$$
C A R(-1,1)_{i}=A R_{i,-1}+A R_{i, 0}+A R_{i, 1}
$$

\section{3.d. Calculation of cumulative abnormal CDS spread (CAS)}

We also use standard event study techniques to calculate unexpected changes in CDS spreads in response to the announcement events. First, we calculate daily CDS abnormal spreads (AS) for each contract as:

$$
A S_{i, t}=\text { Spread }_{i, t}-\text { Rating_Matched_Index_Spread } t
$$

where Spread $_{\mathrm{i}, \mathrm{t}}$ is the end-of-day spread quote of contract $\mathrm{i}$ on event day $\mathrm{t}$, and is the ratingmatched (investment-grade or speculative-grade) CDS index spread on event day t. We then calculate the three-day cumulative CDS abnormal spread (CAS) for each contract as:

$$
C A S_{i, t}=A S_{i, 1}-A S_{i,-1}
$$

where $A S_{i, 1}$ is the CDS abnormal spread at the end of the next trading day after the equity issuance announcement by firm i, and $A S_{i,-1}$ is the CDS abnormal spread one day before the announcement.

Unexpected movements in the CDS spread measure the perceived impact on the cost of purchasing default insurance on the issuing institution. Unexpected changes in stock returns measure the valuation impact on the residual claimholders (shareholders) due to the firm's equityraising action. Throughout the analysis, we use the three-day cumulative abnormal CDS spread (CAS) and cumulative abnormal stock return (CAR) as the key measures of the market reactions.

\section{Results and discussions}




\section{4.a. Average unexpected reactions in CDS and equity markets}

Table 2 summarizes CDS market reactions to 129 seasoned equity issuance announcements made by 56 financial firms and 356 announcements made by 172 nonfinancial firms between 2002 and 2013. We report the average CAS for the whole sample period and two sub periods, the "precrisis" period and "crisis" period. Panel A presents results based on the split using the collapse of Bear Stearns (3/24/2008) to delineate the beginning of the crisis period and panel B reports numbers based on the split using the TARP CPP announcement (10/14/2008) to delineate the beginning of the crisis period.

Over the entire sample period, 2002 through 2013, the market-adjusted CDS spread for financial firms (i.e., the default insurance premium) drops by an average 10.12 bps (see row "Total") over a three-day window in response to equity issuances announcements. This effect is statistically significant at the $1 \%$ level, suggesting that equity financing activities by financial firms are generally favorably received by CDS investors. That is, the price of default insurance, in the form of CDS, decreases at the announcement of stock issuances by financial firms.

Looking at results for the two sub-periods, we see that significantly stronger reactions are concentrated in the crisis period. Using the acquisition of Bear Stearns by J.P. Morgan to delineate the start of the crisis, the three-day average CAS is -16.15 bps in the crisis period (panel A). Using the announcement of the TARP CPP program to delineate the start of the crisis, the two-day average CAS is -18.84 bps in the crisis period (panel B). In contrast, pre-crisis period estimated reactions appear to be insignificant both statistically and economically. Using the acquisition of Bear Stearns by J.P. Morgan to delineate the start of the crisis, the average CAS is -2.75 bps in the pre-crisis period (panel A). Using the announcement of the TARP CPP program to delineate the start of the crisis, the average CAS is $-2.54 \mathrm{bps}$ in the pre-crisis period (panel B). In both cases, the 
crisis period CAS estimates are highly significant and larger in magnitude than the pre-crisis period (the t-statistics for the differences in CAS between the crisis and pre-crisis period are 1.93 (significant at 5.7\%) and 2.07 (significant at $4.2 \%$ ) in panels A and B, respectively.

The estimated reactions appear economically significant when benchmarked with the normal market level in the 2002-2008 period. The raw CDS spread of the sample firms averages around $70 \mathrm{bps}$ in this period. With this backdrop, the market-adjusted reaction in the crisis period accounts for more than $20 \%$ (e.g., $-16.15 \mathrm{bps} / 70 \mathrm{bps}$ ) of the general market level in the pre-crisis period, regardless of the cutoff point we use for defining the crisis period. Thus, equity financing activities by financial firms are received most favorably by CDS investors in the crisis period. Financial firms that issued stock during the financial crisis experienced a steep drop in the price of default insurance.

Finally, comparing the results for financial firms to those of nonfinancial firms, we find differences. Using the acquisition of Bear Stearns by J.P. Morgan to delineate the start of the crisis period, the two-day average CAS for nonfinancial firms is $-42.71 \mathrm{bps}$ in the crisis period (panel A). Using the announcement of the TARP CPP program to delineate the start of the crisis period, the two-day average CAS is -45.70 bps in the crisis period (panel B). In contrast to the results for financial firms, neither of these is statistically significant. However, estimated reactions in the precrisis period appear to be significant. The two-day average CAS is -3.26 bps (significant at $10 \%$ ) in panel $\mathrm{A}$ and -4.80 bps (significant at $5 \%$ ) in panel B. Finally and in contrast to the results for financial firms, for nonfinancial firms the crisis period CAS estimates are not significantly different from the pre-crisis period CAS estimates (the t-statistics for the differences in CAS between the crisis and pre-crisis period are 1.32 and 1.24 in panels $\mathrm{A}$ and $\mathrm{B}$, respectively). 
Table 3 presents evidence on the stock market reactions to stock issue announcements by financial and nonfinancial firms. Adjusted for systematic pricing factors, the stock market overall reacted negatively to seasoned stock offerings by financial firms over the period 2002 through 2013. ${ }^{14}$ Three-day cumulative abnormal stock returns (CARs) average $-1.43 \%$, significant at the 10\% level. This magnitude is comparable with earlier evidence, e.g., Cornett et al. (1998) find an average two-day CAR of $-1.62 \%$ for seasoned equity issuances by financial institutions.

Looking at the pre-crisis and the crisis periods separately, we find insignificantly larger (negative) reactions in the crisis period. Using the acquisition of Bear Stearns by J.P. Morgan to delineate the start of the crisis period, the mean CAR, $-0.69 \%$, is insignificant in the pre-crisis period. However, common stock issuances induce an average CAR of $-2.02 \%$ (significant at $10 \%$ ) in the crisis period. Using the announcement of the TARP CPP program to delineate the start of the crisis period, the pre-crisis mean CAR is $-1.30 \%$, while the crisis period mean CAR is $-1.58 \%$ (both are insignificant). Further, the t-statistics for the differences in CAR between the crisis and pre-crisis period are 0.85 in panel A and 0.18 in panel B and are both are insignificant.

While the general conclusion from these results are that financial firm stock return reactions to seasoned equity issuances are not significantly different before versus during the financial crisis, when benchmarked with normal market conditions, the estimated market reactions appear rather significant. For example, during the crisis period, the average CAR $(-2.02 \%$, using the acquisition of Bear Stearns by J.P. Morgan as the start of the crisis period) is almost 40 times larger than the average raw return $(0.051 \%)$ of the issuing institutions' stocks in the pre-crisis period. Thus, during the crisis, stock investors held markedly more negative views toward financial firms' equity financing activities.

\footnotetext{
${ }^{14}$ We were only able to obtain stock market data for 123 of the 129 equity issue announcements by financial firms and 337 of the 356 announcements by nonfinancial firms. Thus, the number of events drops slightly.
} 
As mentioned above, the TARP CPP was intended to inject equity into financial institutions that were suffering from temporary liquidity and other financial problems due to the financial crisis, but were otherwise in decent shape. These government capital injections need to be analyzed not only in terms of certification effects, but also in terms of how they impact investor perceptions of future regulatory action. While a capital injection certainly implies confidence in a financial firm's viability, it is different from a pure certification exercise like the Supervisory Capital Assessment Program (SCAP, more often known as bank stress tests) or the Depression-era bank holiday in that it alters the risk to taxpayers from a subsequent failure and may therefore influence regulators' behavior. Before the crisis, the U.S. government typically stood in a 'third-todefault" position (through the FDIC guarantee on deposits) behind shareholders, other capital providers, and unsecured creditors. After a TARP CPP injection, it moved to a "second-to-default" position behind shareholders.

It is worth pausing to consider what counts as "default" in this context. Under the terms of the FDICIA of 1991, banks are not subject to regular bankruptcy proceedings with normal creditor rights (the Wall Street Reform and Consumer Protection Act of 2010 has effectively extended this treatment to a range of financial holding companies). The event of default is the point at which the FDIC seizes the operating bank subsidiary; the common equity of the bank is typically wiped out entirely and unsecured creditors are provided with a discounted payoff decided by the FDIC. Well ahead of seizure, however, the bank's supervisors might also force the bank to raise capital even if this issuance is not in the best interest of shareholders. ${ }^{15}$ The analytical objective for an analyst or investor is therefore to judge when regulatory intervention will occur and what losses they are subjected to post-intervention.

\footnotetext{
${ }^{15}$ One can imagine that investors, in an uncorrelated but otherwise identical set of banks, might decide to limit their losses on any one bank in order to preserve their upside gains on the portfolio as a whole.
} 
The immediate reaction to the announcement of capital injections through the TARP CPP focused on the certification effect; the program targeted "healthy" banks, the terms of the preferred stock seemed attractive, and the objective appeared to be to boost confidence in the financial system. The fact that government capital was now subordinate to unsecured creditors also served as a form of "seizure insurance" for anxious investors who had just experienced the shock of government-imposed losses on the collapse of Washington Mutual. But what happened next is instructive:

1. Bank capital has historically been measured mainly on the basis of Tier 1 capital ratios ((common equity + qualifying preferred stock) to risk-weighted assets). Differences in Tier 1 capital ratios across banks provided important information about banks' relative profitability, risk tolerance, and access to capital. Analysts and money managers used Tier 1 capital ratios almost exclusively to identify differences among banks. Preferred stock issued to the government through the TARP CPP qualified as Tier 1 capital. The injection of government capital, which amounted to approximately $3 \%$ of risk-weighted assets for virtually all publicly traded banks, made Tier 1 comparisons less meaningful. ${ }^{16}$ Not surprisingly, the focus of analysts and money managers shifted to the Tangible Common Equity (TCE) ratio (common equity to tangible assets) since this measure did not include TARP CPP preferred stock: comparisons made on the basis of TCE remained undiluted. By early 2009 market participants were focusing almost exclusively on TCE and Tier 1 Common (common equity to risk-weighted assets) ratios. In the process, TARP CPP capital, as well as all other non-common equity Tier 1 capital, issued by banks had become essentially moot as measure used to evaluate bank health.

\footnotetext{
${ }^{16}$ Indeed, in a couple of cases that banks canceled planned equity raises once CPP was announced - a great real world example of Gresham's law at work.
} 
2. By design preferred stock issued through TARP CPP, was made senior to common equity in order to protect taxpayers from loss. So, while creditors obtained an additional buffer against losses in the event of default, shareholders did not - they remained in a first loss position. Shareholders might reasonably suspect that the government would be more prone to intervene if a TARP CPP bank got into trouble given that the government was now in a second loss position and had lost the buffer provided by other forms of regulatory capital and unsecured debt. Indeed, the higher loss outcomes could more than offset the certification effect. However, the continued decline in bank stocks in the period between the announcement of TARP CPP and the release of the first bank stress test (SCAP) results (see Figure 3) suggests equity investors did not in fact see TARP CPP capital injections as reducing their risk. Moreover, the unpopularity of the program, the addition of "strings" by Congress and the focus on getting the money back all made TARP CPP increasingly seem like expensive capital ${ }^{17}$ that could not absorb losses or be leveraged like common equity. Given these two considerations, it is not surprising that equity market reactions to new stock issuances by financial firm are larger in the crisis period relative to the pre-crisis period. However, while equity market reactions are larger in the crisis period, they are not significantly so. In part, this may be because the certification effect was more robust; differentiating amongst banks in terms of capital needs provided more information and the capital raised was fully loss absorbing. ${ }^{18}$

\footnotetext{
${ }^{17}$ As public outrage swelled over the rapidly growing cost of 'bailing out' financial institutions, the Obama administration and lawmakers attached more and more restrictions on banks that received TARP funds. For example, with the acceptance of TARP funds, banks were told to put off evictions and modify mortgages for distressed homeowners, let shareholders vote on executive pay packages, slash dividends, and withdraw job offers to foreign citizens. Some bankers stated that conditions of the TARP program had become so onerous that they wanted to return the bailout money as soon as regulators set up a process to accept the repayments. For example, just three months after receiving TARP funds, Signature Bank of New York announced that because of new executive pay restrictions assessed as a part of the acceptance of TARP funds, it notified the Treasury that it intended to return the \$120 million it had received.

${ }^{18}$ It is also instructive to contrast the reaction to TARP CPP with the subsequent release of stress test results and associated capital raising. Even though many banks were forced to undertake dilutive capital raises to satisfy the
} 
Finally from table 3, comparing the results for financial firms to those of nonfinancial firms, we again find differences. Using the acquisition of Bear Stearns by J.P. Morgan to delineate the start of the crisis period, the two-day average CAR for nonfinancial firms is $-1.10 \%$ in the precrisis period (panel A). Using the announcement of the TARP CPP program to delineate the start of the crisis period, the two-day average CAR is $-1.77 \%$ in the pre-crisis period (panel B). In contrast to the results for financial firms, both of these are significant at $5 \%$ and $1 \%$, respectively. However, neither is significantly different from the CARs for financial firms $(-0.69 \%$ and $-1.30 \%$, respectively). Similarly, in the crisis period the two-day average CAR is $-3.89 \%$ (significant at $1 \%$ ) in panel A and $-3.70 \%$ (significant at $1 \%$ ) in panel B. In contrast to the results for financial firms, the crisis period CARs are significantly larger than the pre-crisis period CARs (the tstatistics for the differences in CARs between the crisis and pre-crisis period are 5.00 and 2.96 in panels A and B, respectively). Finally, the crisis period CARs for nonfinancial firms are larger than the crisis period CARs for financial firms (the t-statistics for the differences in CARs are 1.55 and 1.73 in panels $\mathrm{A}$ and $\mathrm{B}$, respectively).

Remembering that the TARP CPP program injected capital into financial institutions that were suffering from temporary problems, these results make sense. TARP CPP injections certified the long-term viability of the financial firms that received funds. However, TARP CPP funds were not provided to nonfinancial firms. As a result, these firms were left more susceptible to losses and even failure resulting from the financial crisis. Thus, it is not surprising that the crisis period CARs for financial firms (that were receiving capital injections from the federal government) are

SCAP requirements and/or exit TARP, share prices generally rallied. This may also be because the certification effect was more robust. The government also played an entirely supervisory role and was not muddying their certification role by taking direct risk. Also, since the government was now at risk once a bank exhausted its TCE, it was logical for investors to focus on TCE levels as the best indicator of effective default risk - this adds to the arguments already listed in item 1. 
significantly larger (less negative) than the crisis period CARs for financial firms (that did not receive such capital injections).

Combining the results from tables 2 and 3, we find that price of default insurance (measured as abnormal changes in the CDS spreads) of financial firms that issue equity during the financial crisis is lowered significantly. As a result, as these financial firms issue equity after the crisis, their abnormal stock returns (CARs) are not significantly more negative than the pre-crisis period. In contrast, default risk for nonfinancial firms did not decrease significantly during the crisis. As a result, equity issuances by these firms resulted in significantly larger negative CARs. A reason for the differences between financial firms and nonfinancial firms may be due to the government sponsored TARP CPP program that injected equity into financial firms during the crisis. Equity injections through TARP CPP left the financial firms less exposed to failure during the crisis. The market reacted to this by assessing lower costs for default protection via credit default swaps and insignificant changes in returns on equity issue announcements. Nonfinancial firms had no such injections and were thus left more susceptible to the financial crisis. The market reacted to the crisis by assessing no abnormal decreases in costs for default protection via CDSs and larger negative returns on equity issue announcements.

\section{4.b. Market reactions and firm/issuance characteristics}

Having examined the CASs and CARs in isolation, we next relate the cross-sectional variation of market reactions to firm and issuance characteristics. Specifically, we regress the three-day CAS and CAR estimates on a risk measure-a dummy for being speculative-grade rated, ${ }^{19}$ the issue size as a percent of the market capital of the firm, ${ }^{20}$ and a set of firm

\footnotetext{
${ }^{19}$ There are 13 institutions, $11 \%$ of the sample firms, which are rated speculative grade.

${ }^{20} \mathrm{We}$ also examined the log of this variable. Results are generally of the same sign, but less significant.
} 
characteristics $^{21}$ as controls (we include log of assets, leverage, stock volatility, and ROA). The high yield dummy is equal to 1 if the stock issuing financial firm is rated as speculative, and 0 otherwise. Ratings and issue size are obtained from S\&P's Capital IQ. Market capital is measured as the market price of the firm's stock one month prior to the stock issue announcement (obtained from CRSP) times the number of shares of common stock outstanding. Assets is the book value of the firm's assets at quarter end before the stock issue announcement. Leverage is total debt divided by total assets at quarter end before the stock issue announcement. ROA is annualized net income divided by total assets at quarter end before the stock issue announcement. Volatility is the standard deviation in the firm's stock prices in the quarter prior to the stock issue announcement. All balance sheet data are obtained from Call Reports and/or SEC 10-Q filings. In the regressions, we cluster standard errors by bank.

Table 4 presents descriptive statistics on the regressions variables. The mean value of the sample firms is $\$ 333.78$ billion, ranging from $\$ 2.42$ billion to $\$ 2.02$ trillion. Thus, the sample includes both smaller and large financial firms. The mean issue size represents $19.76 \%$ of the preissue market capital, and ranges from $0.00 \%$ to $567.69 \%$. The sample firms have a mean leverage of $86.38 \%$ before the equity issuance, ranging from $37.79 \%$ to $97.80 \%$. The mean ROA for the sample firms is $-0.55 \%$ and ranges from $-76.03 \%$ to $48.17 \%$. Thus, the sample includes firms that performed very well and very poorly over the sample period, a time frame that includes a period of record profits for the financial institutions industry as well as the financial crisis which hurt financial firm profitability tremendously.

Table 5 presents the regressions results. Columns 1 through 3 present results using the three-day cumulative CDS abnormal spread (CAS) as the dependent variable, while columns 4 through 6 present results using the three-day cumulative abnormal stock returns (CAR) as the

\footnotetext{
${ }^{21}$ The regression sample decreases due to the requirement of non-missing data for both LHS and RHS variables.
} 
dependent variable. Regressions 1 and 4 include only the "high yield dummy" as an independent variable. Regressions 2 and 5 include the "high yield dummy" and the firm control variables. Finally, regressions 3 and 6 include the "high yield dummy," the relative issue size, and the firm control variables as independent variables.

Examining the regression results, it is evident that issuer risk is a significant determinant of the CDS reactions to stock issuances by financial firms. The "high yield dummy" is negative with persistent significance in all CAS regressions (models 1 through 3), e.g., the coefficient is -36.451 , significant a $1 \%$, in regression 1 ; the coefficient is -25.556 , significant a $5 \%$, in regression 2 ; and is -25.555 , significant a $5 \%$, in regression 3 . The results suggest that equity issuances by riskier firms are associated with abnormal decreases in CDS spreads (i.e., the price of default insurance decreases), ranging from 25.555-36.451 bps. Similarly, regressions 4 through 6 suggest that stock market reactions to equity issuances by financial firms are more positive, albeit not consistently significant, for high risk firms, e.g., the coefficient is 2.853 , significant at $10 \%$, in regression 4 and is 3.396 , insignificant, in both regressions 5 and 6 . The average CAR of $-1.43 \%$ (see table 3 ) is higher, by $2.853 \%-3.396 \%$, if the firm is rated speculative grade.

Examining regressions 3 and 6, abnormal changes in CDS spreads in response to stock issuances by financial firms do not appear to be sensitive to the size of issuance; issue size as a percent of market capital is insignificant (coefficient $=-0.007$ ). Further, stock market reactions are not significantly related to the issue size (coefficient $=0.001$ ). These results are consistent with the notion that larger issue size (relative to firm value) is insignificant news for CDS (lower CAS) and stock investors. ${ }^{22}$ Despite the lack of significance of the issuance size estimate, signs are consistent with the notion that larger issuance size (relative to market capital) is favorable news for both CDS

\footnotetext{
${ }^{22}$ In unreported results, we also try to detect non-linear relationship using discrete dummy-based measures for different quartiles of the issuance size measure. We do not find any significant relationship, which we attribute to the limited size of our sample.
} 
(lower CAS) and stock (higher CAR) investors. Finally, comparing regressions 2 and 3 vs regression 1 (and regressions 5 and 6 vs regression 4) we see that the inclusion of various controls for firm characteristics does not appear to alter the key findings. This is not surprising given that much of this firm specific financial information is incorporated in the credit rating measure. ${ }^{23}$

Table 6 reports regression results split according to time period. Panel A of table 6 reports results using the acquisition of Bear Stearns by J.P. Morgan to delineate the start of the crisis period, while panel B reports results using the announcement of TARP CPP to delineate the start of the crisis period. ${ }^{24}$ The regression results appear to differ significantly across the pre-crisis and the crisis sub-periods. The results in the pre-crisis period for both panels A and B are similar to, yet more significant than, those in table 5. The "high yield dummy" is negative and significant at the 5\% level in all CAS regressions (models 1 through 3), again suggesting that equity issuances by riskier firms are associated with decreases in CDS spreads (i.e., the price of default insurance decreases). Yet now we see that the increase in CDS spreads ranges from 20.951-34.680 bps. Further, regressions 4 through 6 suggest that stock market reactions to equity issuances by high risk financial firms are more positive, and now consistently significant, e.g., in panel A the coefficient is 7.246 in regression 4 ; the coefficient is 20.519 in regression 5 ; and is 20.245 in regression 6 , all significant at $10 \%$ or better. Thus, issuer risk is a significant determinant of the CDS and stock market reactions to stock issuances by financial firms before the financial crisis. ${ }^{25}$ Equity issuances by riskier firms are associated with significant abnormal decreases in CDS spreads and significant abnormal increases in stock market values.

\footnotetext{
${ }^{23}$ The signs of the controls are generally consistent with existing evidence, but there is no persistent significance in any control among a number of specifications that we tested.

24 In both panels, 3 of the high yield firms announce equity issuances in the pre-crisis period, while 10 announce equity issuances in the crisis period.

${ }^{25}$ We also examine regressions in which we interact the key variables with period dummies. Results are similar to those reported in tables 5 and 6 . They are available from the authors on request.
} 
Examining regressions 3 and 6, abnormal changes in CDS spreads in response to stock issuances by financial firms are now positively related to the size of issuance; issue size as a percent of market capital is significant (coefficient $=0.027$ in Panel A and 0.020 in Panel B, both significant at $10 \%)$ ). Further, stock market reactions are now negatively related to the issue size (coefficient $=-0.009$ in Panel A, insignificant, and -0.020 in Panel B, significant at 10\%)). Thus, prior to the financial crisis the larger the issue size (relative to firm value), the larger the abnormal increase in CDS spreads and decrease in stock values. This is consistent with the notion that larger issuance size (relative to market capital) is negative news for both CDS and stock investors.

In both panels $\mathrm{A}$ and $\mathrm{B}$ of table 6 we see that results in the pre-crisis period virtually disappear and even reverse in the crisis period. For the crisis period regressions, the "high yield dummy" is insignificant in two of the three CAS regressions (only regression 1 reports a significant coefficient, -38.549 , significant at 5\%, in Panel A and -36.522, significant at 10\%, in Panel B). Thus, the risk of the issuing firm has no or a much smaller effect on the price of default insurance during the financial crisis. Further, the coefficients on the "high yield dummy" are insignificant in the CAR regressions panel A models 4 through 6 and panel B model 4 , are positive and significant (at 10\%) in panel B model 4 (coefficient $=1.464)$, and are negative and significant (at 5\%) in panel B model 6 (coefficient $=-3.490$ ). These results suggest that during the financial crisis higher risk firms see no consistent abnormal change in stock values at the announcement of an equity issue. As discussed above, preferred stock issued through the TARP CPP program was made senior common stock, but not to other capital providers. Thus, creditors obtained an additional buffer against losses in the event of default. As a result, the certification effect of an equity issue announcement prior to the financial crisis is not necessarily the dominant 
effect during the crisis. During the financial crisis, issuances of equity by higher risk financial firms did not provide the same signal of expected poor performance as they did before the crisis.

As a final test, we use S\&P's Expected Default Frequency (EDF) measure to assess how equity issuances affect the perceived default likelihood during different time horizons. For 82 announcements, we are able to collect EDF data for horizons of 1, 2 and 3 years. ${ }^{26}$ Seven of these 82 announcements involve high yield firms. EDF is the percent change in the S\&P Expected Default Frequency (EDF) for the firm for 1-year, 2-year, and 3-year horizons beginning from the quarter before the stock issue announcement. Descriptive statistics for percent change in the EDF are reported in Table 4. The mean change runs from $2.30 \%$ to $2.62 \%$ for the 1-year, 2-year, and 3 year EDF, respectively, and the minimum and maximum changes run from $0.01 \%$ to $24.63 \%$ for the three measures of change in default risk.

Regression results are reported in table 7 . The regression specification in table 7 is identical to that in table 5, except that the dependent variable is the percentage change in the EDF for a 3-day period ( $\mathrm{t}=-1$ to +1$)$ around the announcement date. Consistent with the CDS market reactions documented earlier in table 5, table 7 shows that the EDF measure decreases significantly more among riskier institutions, as reflected by the "high yield dummy" coefficient which is negative and significant (coefficient $=-23.402$ in regression $1,-22.581$ in regression 2 , and -21.296 in regression 3 (all are significant at 10\%)). Further, changes in the EDF measures in response to stock issuances by financial firms appear to be sensitive to the size of issuance; issue size as a percent of market capital is significant and negative in all three regressions. That is, larger issuances are associated with larger decreases in the EDF risk measure.

\section{4.c. Sampling Alternatives}

\footnotetext{
${ }^{26}$ S\&P does not provide daily EDF data until June 2006. Given the focus on daily change in EDF around the equity issue announcement day, we are not able to include announcements before June 2006. This prohibits us from being able to isolate relations before versus during the financial crisis.
} 
The results reported throughout the paper are based on a sample 129 equity issuances by financial firms. We expand the sample to include (1) equity issue announcements involving both common stocks and other security types such as preferred stock, options, warrants, etc. and (2) REITs-related financial firms. In both cases, all findings and interpretations remain unchanged and in many cases the estimates appear even stronger statistically.

\section{Concluding remarks}

In this paper, we study CDS and equity market reactions to seasoned equity issuances that were announced by financial companies between 2002 and 2013. We split the sample period, analyzing market reactions before and during the financial crisis. We measure the change in the market's perception of the probability of firm default by analyzing CDS data. We find that CDS prices respond quickly to new, default-relevant information. Over the full sample period, cumulative abnormal CDS spreads (CAS) drop significantly in response to equity issuance announcements. Further, the reactions are significantly stronger during the financial crisis. Crosssectional analysis suggests equity issuances by riskier institutions (rated speculative grade) are received more favorably in the CDS market and by stock investors. However, the relations fail to hold during the financial crisis. During the financial crisis, the federal government injected equity into financial institutions. The equity was made senior to common stock, but not to other capital providers. Thus, the market reacted to this by assessing lower costs for default protection via credit default swaps and insignificant changes in returns on equity issue announcements. Further, creditors obtained an additional buffer against losses in the event of default. As a result, the certification effect of an equity issue announcement prior to the financial crisis was not necessarily the dominant effect during the crisis. During the financial crisis, issuances of equity by higher risk 
financial firms did not provide the same degree of default-relevant information as they did before the crisis. Thus, the evidence indicates that single named CDSs based on financial firms' default probabilities are potentially useful for private investors and regulators. 
Table 1

\section{Number and Relative Size of Equity Issuances by Financial and Nonfinancial Firms by Year}

This table reports the year-by-year distribution of seasoned equity issue announcements by financial and nonfinancial firms. The initial sample is collected from S\&P's Capital IQ database. We then limit the sample to those firms having CDS pricing data reported by Markit. The final sample includes data on 485 equity issuances by 56 financial institutions and 172 nonfinancial firms. Of the 485 announcements, 129 involve equity issuances by financial firms, with the rest including issuances by nonfinancial firms. Panel A of the Table reports the average dollar amount of equity issued. Panel B reports the means and standard deviations of the distribution of dollar values of equity issuances relative to the issuing firms' market capitalizations.

\section{Panel A: Size and number of equity issuances}

\begin{tabular}{ccc|cc|cc}
\multicolumn{2}{c|}{ Financial Firms } & \multicolumn{2}{c|}{ Nonfinancial Firms } & \multicolumn{2}{c}{ All Issuances } \\
\hline Year & $\begin{array}{c}\text { Amount } \\
\text { Issued (in } \\
\text { billions) }\end{array}$ & $\mathbf{N}$ & $\begin{array}{c}\text { Amount } \\
\text { Issued (in } \\
\text { billions) }\end{array}$ & $\mathbf{N}$ & $\begin{array}{c}\text { Amount } \\
\text { Issued (in } \\
\text { billions) }\end{array}$ & $\mathbf{N}$ \\
\hline 2002 & $\$ 1.46$ & 5 & $\$ 11.72$ & 22 & $\$ 13.18$ & 27 \\
2003 & 4.99 & 10 & 24.70 & 28 & 29.69 & 38 \\
2004 & 0.81 & 4 & 13.30 & 24 & 14.11 & 28 \\
2005 & 23.89 & 12 & 9.08 & 19 & 32.97 & 31 \\
2006 & 30.51 & 17 & 10.88 & 21 & 41.39 & 38 \\
2007 & 17.81 & 6 & 10.95 & 21 & 28.77 & 27 \\
2008 & 62.09 & 22 & 28.59 & 36 & 90.68 & 58 \\
2009 & 51.11 & 21 & 20.96 & 52 & 72.08 & 73 \\
2010 & 30.26 & 12 & 15.23 & 40 & 45.49 & 52 \\
2011 & 19.90 & 8 & 19.43 & 30 & 39.33 & 38 \\
2012 & 28.17 & 7 & 11.27 & 31 & 39.43 & 38 \\
2013 & 4.16 & 5 & 12.48 & 32 & 16.64 & 37 \\
\hline Total & $\mathbf{\$ 2 7 5 . 1 6}$ & $\mathbf{1 2 9}$ & $\mathbf{\$ 1 8 8 . 5 8}$ & $\mathbf{3 5 6}$ & $\mathbf{\$ 4 6 3 . 7 4}$ & $\mathbf{4 8 5}$ \\
\hline
\end{tabular}


Table 1 (continued)

Panel B: Means and standard deviations of the distribution of dollar values of equity issuances relative to the issuing firms' market capitalizations

\begin{tabular}{ccc|cc|c}
\multicolumn{2}{c|}{ Financial Firms } & \multicolumn{2}{|c|}{ Nonfinancial Firms } & \\
\hline Year & $\begin{array}{c}\text { Mean } \\
(\boldsymbol{\%})\end{array}$ & $\begin{array}{c}\text { Std Dev } \\
\mathbf{( \% )}\end{array}$ & $\begin{array}{c}\text { Mean } \\
\mathbf{( \% )}\end{array}$ & $\begin{array}{c}\text { Std Dev } \\
\mathbf{( \% )}\end{array}$ & $\begin{array}{c}\text { Difference } \\
\text { in Means } \\
\text { P-Value }\end{array}$ \\
\hline 2002 & 4.29 & 3.46 & 7.95 & 5.73 & 0.1861 \\
2003 & 6.14 & 6.51 & 6.57 & 5.18 & 0.8355 \\
2004 & 11.14 & 6.51 & 9.38 & 8.49 & 0.6963 \\
2005 & 17.72 & 20.15 & 15.60 & 11.76 & 0.7125 \\
2006 & 37.01 & 136.84 & 7.79 & 6.13 & 0.3333 \\
2007 & 8.37 & 7.39 & 10.91 & 8.34 & 0.5084 \\
2008 & 24.36 & 24.09 & 8.67 & 7.04 & 0.0005 \\
2009 & 17.11 & 18.88 & 10.13 & 8.20 & 0.0300 \\
2010 & 20.19 & 24.11 & 10.26 & 9.80 & 0.0391 \\
2011 & 10.73 & 3.75 & 6.31 & 4.55 & 0.0163 \\
2012 & 9.61 & 3.32 & 6.43 & 5.12 & 0.1268 \\
2013 & 38.74 & 43.75 & 6.46 & 4.46 & 0.0004 \\
\hline Total & $\mathbf{1 9 . 4 1}$ & $\mathbf{5 2 . 4 0}$ & $\mathbf{8 . 7 9}$ & $\mathbf{7 . 6 3}$ & $\mathbf{0 . 0 0 0 2}$ \\
\hline
\end{tabular}


Table 2

Cumulative abnormal CDS spreads (CAS) in response to seasoned equity issuances

This table reports CDS market reactions to 485 seasoned equity issuance announcements made by 56 financial and 172 nonfinancial firms between 2002 and 2013. We calculate daily CDS Abnormal Spreads (AS) for each contract as:

$$
A S_{i, t}=\text { Spread }_{i, t}-\text { Rating_Matched_Index_Spread }
$$

where Spread $_{\mathrm{i}, \mathrm{t}}$ is the end-of-day spread quote of contract $\mathrm{i}$ on event day $\mathrm{t}$, and is the rating-matched (investment-grade or speculative-grade) CDS index spread on event day t. We then calculate the three-day cumulative CDS Abnormal Spread (CAS) for each contract as:

$$
C A S_{i, t}=A S_{i, 1}-A S_{i,-1}
$$

where $A S_{i, 1}$ is the CDS abnormal spread at the end of the next trading day after the equity issuance announcement by institution $\mathrm{i}$, and $A S_{i,-1}$ is the CDS abnormal spread one day before the announcement. Panel A presents results based on the split using the collapse of Bear Stearns (3/24/2008) to delineate the beginning of the crisis period, and panel $\mathrm{B}$ reports numbers based on the split using the TARP CPP announcement (10/14/2008) to delineate the beginning of the crisis period.

Panel A - Crisis period starts with Bear Stearns acquisition by J.P. Morgan announcement

\begin{tabular}{|c|c|c|c|c|c|c|c|c|c|}
\hline \multicolumn{5}{|c|}{ Financial Firms } & \multicolumn{5}{|c|}{ Nonfinancial firms } \\
\hline Years & $\mathrm{N}$ & CAS (bps) & $\begin{array}{l}\text { Mean } \\
\text { Spread } \\
\text { (bps) }\end{array}$ & $\begin{array}{c}\text { Std Dev } \\
\text { Spread } \\
\text { (bps) }\end{array}$ & Years & $\mathrm{N}$ & CAS (bps) & $\begin{array}{l}\text { Mean } \\
\text { Spread } \\
\text { (bps) }\end{array}$ & $\begin{array}{c}\text { Std Dev } \\
\text { Spread } \\
\text { (bps) }\end{array}$ \\
\hline Pre-crisis & 58 & -2.75 & 1.35 & 2.11 & Pre-crisis & 142 & $-3.26^{*}$ & 2.14 & 2.85 \\
\hline Crisis & 71 & $-16.15^{* *}$ & 3.11 & 2.53 & Crisis & 214 & -42.71 & 3.73 & 5.00 \\
\hline Total & 129 & $-10.12 * * *$ & 2.32 & 2.50 & Total & 356 & -26.97 & 3.10 & 4.34 \\
\hline
\end{tabular}

Pre-crisis period: 1/1/2002 - 03/24/2008_Crisis period: 03/25/2008 - 01/20/2011

Panel B - Crisis period starts with TARP CPP announcement

\begin{tabular}{|c|c|c|c|c|c|c|c|c|c|}
\hline \multicolumn{6}{|c|}{ Financial Firms } & \multicolumn{4}{|c|}{ Nonfinancial firms } \\
\hline Years & $\mathrm{N}$ & CAS (bps) & $\begin{array}{l}\text { Mean } \\
\text { Spread } \\
\text { (bps) }\end{array}$ & $\begin{array}{l}\text { Std Dev } \\
\text { Spread } \\
\text { (bps) }\end{array}$ & Years & $\mathrm{N}$ & CAS (bps) & $\begin{array}{l}\text { Mean } \\
\text { Spread } \\
\text { (bps) }\end{array}$ & $\begin{array}{c}\text { Std Dev } \\
\text { Spread } \\
\text { (bps) }\end{array}$ \\
\hline Pre-crisis & 69 & -2.54 & 1.68 & 2.26 & Pre-crisis & 163 & $-4.80 * *$ & 2.47 & 3.40 \\
\hline Crisis & 60 & $-18.84 * *$ & 3.06 & 2.57 & Crisis & 193 & -45.70 & 3.62 & 4.95 \\
\hline Total & 129 & $-10.12 * * *$ & 2.32 & 2.50 & Total & 356 & -26.97 & 3.10 & 4.34 \\
\hline
\end{tabular}

Pre-TARP period: $1 / 1 / 2002-10 / 14 / 2008 \quad$ Post-TARP period: 10/14/2008 - 01/20/2011

$* * * \mathrm{p}<0.01, * * \mathrm{p}<0.05, * \mathrm{p}<0.10$ 


\section{Table 3}

Cumulative abnormal stock returns (CARs) in response to equity issuances

This table reports equity market reactions to 337 equity issuance announcements made by 56 financial and 172 nonfinancial firms between 2002 and 2013. We use standard event study techniques to calculate unexpected changes stock prices in response to the announcement events. Specifically, we calculate normal stock return performance using a 125 trading day window, ending five trading days before the announcement date. A Fama-French three factor model is used to predict the expected excess return:

$$
\operatorname{Return}_{\text {excess } i, t}=\alpha+\beta_{1}\left(\text { Market }-R_{f}\right)_{t}+\beta_{2}(S M B)_{t}+\beta_{3}(H M L)_{t}
$$

where $R_{f}$ is the risk-free return rate, $S M B$ stands for "small (market capitalization) minus big," and $H M L$ stands for "high (book-to-market ratio) minus low." The abnormal return, $A R_{i, t}$, is then calculated as the

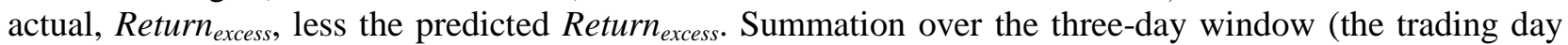
before the announcement, the announcement day, and the following trading day) gives the three-day announcement period cumulative abnormal stock returns (CARs),

$$
C A R(-1,1)_{i}=A R_{i,-1}+A R_{i, 0}+A R_{i, 1}
$$

Panel A presents results based on the split using the collapse of Bear Stearns (3/24/2008) to delineate the beginning of the crisis period, and panel $\mathrm{B}$ reports numbers based on the split using the TARP announcement (10/14/2008) to delineate the beginning of the crisis period.

Panel A - Crisis period starts with Bear Stearns acquisition by J.P. Morgan announcement

Pre-crisis period: 1/1/2002 - 03/24/2008

\begin{tabular}{|c|c|c|c|c|c|c|c|c|c|}
\hline \multicolumn{5}{|c|}{ Financial Firms } & \multicolumn{5}{|c|}{ Nonfinancial firms } \\
\hline Years & $\mathrm{N}$ & CAR $(\%)$ & $\begin{array}{c}\text { Mean } \\
\text { Return } \\
(\%)\end{array}$ & $\begin{array}{l}\text { Std Dev } \\
\text { Return } \\
(\%)\end{array}$ & Year & $\mathrm{N}$ & CAR $(\%)$ & $\begin{array}{l}\text { Mean } \\
\text { Return } \\
(\%)\end{array}$ & $\begin{array}{l}\text { Std Dev } \\
\text { Return } \\
(\%)\end{array}$ \\
\hline Pre-crisis & 54 & -0.69 & 0.10 & 3.40 & Pre-crisis & 128 & $-1.10^{* *}$ & -0.73 & 2.76 \\
\hline Crisis & 69 & $-2.02 *$ & -3.66 & 8.66 & Crisis & 209 & $-3.89 * * *$ & -0.73 & 4.25 \\
\hline Total & 123 & $-1.43^{*}$ & -1.38 & 7.15 & Total & 337 & $-2.87 * * *$ & -0.53 & 3.28 \\
\hline
\end{tabular}

Crisis period: 03/25/2008-01/20/2011

Panel B - Crisis period starts with TARP CPP announcement

Pre-TARP period: $1 / 1 / 2002-10 / 14 / 2008$

Financial Firms

\begin{tabular}{l|cccc}
\hline & & & $\begin{array}{c}\text { Mean } \\
\text { Return } \\
(\%)\end{array}$ & $\begin{array}{c}\text { Std Dev } \\
\text { Return } \\
(\%)\end{array}$ \\
\hline Years & $\mathrm{N}$ & CAR (\%) & & \\
\hline $\begin{array}{l}\text { Pre-crisis } \\
\text { Crisis }\end{array}$ & 64 & -1.30 & -0.83 & 7.02 \\
\hline Total & 123 & -1.58 & -3.31 & 6.86 \\
\hline
\end{tabular}

$* * * \mathrm{p}<0.01, * * \mathrm{p}<0.05, * \mathrm{p}<0.10$

Post-TARP period: 10/14/2008 - 01/20/2011

Nonfinancial firms

\begin{tabular}{l|cccc}
\hline & & & $\begin{array}{c}\text { Mean } \\
\text { Return } \\
(\%)\end{array}$ & $\begin{array}{c}\text { Std Dev } \\
\text { Return } \\
(\%)\end{array}$ \\
Year & $\mathrm{N}$ & CAR (\%) & \\
\hline $\begin{array}{l}\text { Pre-crisis } \\
\text { Crisis }\end{array}$ & 149 & $-1.77 * * *$ & -0.97 & 3.27 \\
\hline Total & 337 & $-3.70^{* * *}$ & -0.37 & 3.96 \\
\hline
\end{tabular}




\section{Table 4}

\section{Descriptive statistics for regression variables}

This table reports descriptive statistics for variables used in the regression analysis. The high yield dummy is equal to 1 if the stock issuing financial firm is rated as speculative. Ratings and issue size are obtained from S\&P's Capital IQ. Market capital is measured as the market price of the firm's stock one month prior to the stock issue announcement (obtained from CRSP) times the number of shares of common stock outstanding. Assets is the book value of the firm's assets at quarter end before the stock issue announcement. Leverage is total debt divided by total assets at quarter end before the stock issue announcement. ROA is annualized net income divided by total assets at quarter end before the stock issue announcement. Volatility is the standard deviation in the firm's stock prices in the quarter prior to the stock issue announcement. All balance sheet data are obtained from Call Reports and/or SEC 10-Q filings. EDF is change in the S\&P Expected Default Frequency (EDF) for the firm from the quarter before to the quarter after the stock issue announcement.

\begin{tabular}{lrrrrrr}
\hline Variable & N & Mean & Median & Std Dev & Minimum & Maximum \\
\hline Issue size as a \% of market cap (\%) & 129 & 19.41 & 9.09 & 52.04 & 0.00 & 567.69 \\
Total assets (millions of \$) & 121 & 333,780 & 120,931 & 449,557 & 2,425 & $2,020,966$ \\
Leverage (\%) & 121 & 86.38 & 89.40 & 10.70 & 37.79 & 97.80 \\
ROA (\%) & 121 & -0.55 & 0.86 & 11.36 & -76.03 & 48.17 \\
Stock volatility (\%) & 120 & 3.84 & 2.30 & 3.51 & 14.57 & 19.54 \\
EDF (1-yr) (\%) & 82 & 2.30 & 0.65 & 3.72 & 0.01 & 16.11 \\
EDF (2-yr) (\%) & 82 & 2.53 & 0.79 & 4.05 & 0.01 & 24.19 \\
EDF (3-yr) (\%) & 82 & 2.62 & 0.91 & 4.01 & 0.01 & 24.63 \\
\hline High yield dummy & $1: 13$ & & & & & \\
\end{tabular}




\section{Table 5}

\section{Cross-sectional regression analysis of CAS and CAR market reactions to firm and issuance characteristics}

This table presents cross-sectional regressions of CASs and CARs on firm and issuance characteristics. Specifically, we regress the three-day CAS and CAR estimates on a risk measure (a dummy for being speculative-grade rated), a measure of issuance size to market capital of the firm, and a set of firm characteristics as controls: log of assets, leverage, stock volatility and ROA). The high yield dummy is equal to 1 if the stock issuing financial firm is rated as speculative. Ratings and issue size are obtained from S\&P's Capital IQ. Market capital is measured as the market price of the firm's stock one month prior to the stock issue announcement (obtained from CRSP) times the number of shares of common stock outstanding. Assets is the book value of the firm's assets at quarter end before the stock issue announcement. Leverage is total debt divided by total assets at quarter end before the stock issue announcement. ROA is annualized net income divided by total assets at quarter end before the stock issue announcement. Volatility is the standard deviation in the firm's stock prices in the quarter prior to the stock issue announcement. All balance sheet data are obtained from Call Reports and/or SEC 10-Q filings. Robust t-statistics are in parentheses.

\begin{tabular}{|c|c|c|c|c|c|c|}
\hline \multirow[t]{2}{*}{ Dependent Variable } & \multicolumn{3}{|c|}{ Cumulative abnormal CDS spread } & \multicolumn{3}{|c|}{ Cumulative abnormal stock return } \\
\hline & (1) & $(2)$ & (3) & (4) & $(5)$ & $(6)$ \\
\hline Constant & $\begin{array}{c}-6.315^{*} \\
(0.524)\end{array}$ & $\begin{array}{l}-33.232 \\
(10.379)\end{array}$ & $\begin{array}{l}-32.185 \\
(14.025)\end{array}$ & $\begin{array}{l}-1.692 \\
(0.425)\end{array}$ & $\begin{array}{c}6.408 \\
(2.857)\end{array}$ & $\begin{array}{c}6.270 \\
(3.633)\end{array}$ \\
\hline High yield dummy & $\begin{array}{c}-36.451 * * * \\
(0.524)\end{array}$ & $\begin{array}{c}-25.556 * * \\
(0.469)\end{array}$ & $\begin{array}{c}-25.555^{* *} \\
(0.423)\end{array}$ & $\begin{array}{l}2.853 * \\
(0.415)\end{array}$ & $\begin{array}{c}3.396 \\
(1.766)\end{array}$ & $\begin{array}{c}3.396 \\
(1.767)\end{array}$ \\
\hline Issue size as \% of market cap & & & $\begin{array}{l}-0.007 \\
(0.024)\end{array}$ & & & $\begin{array}{c}0.001 \\
(0.005)\end{array}$ \\
\hline $\begin{array}{l}\text { Control for asset size, leverage, } \\
\text { ROA and volatility }\end{array}$ & NO & YES & YES & NO & YES & YES \\
\hline Observations & 123 & 120 & 120 & 123 & 120 & 120 \\
\hline Adjusted R-squared & $5.8 \%$ & $7.7 \%$ & $6.9 \%$ & $0.2 \%$ & $-1.5 \%$ & $-2.4 \%$ \\
\hline
\end{tabular}

$* * * \mathrm{p}<0.01, * * \mathrm{p}<0.05, * \mathrm{p}<0.1$ 
Table 6

Cross-sectional regression analysis of CAS and CAR market reactions to firm and issuance characteristics in the pre-crisis and crisis periods

This table presents cross-sectional regressions of CASs and CARs on firm and issuance characteristics. Specifically, we regress the three-day CAS and CAR estimates on a risk measure (a dummy for being speculative-grade rated), a measure of issuance size to market capital of the firm, and a set of firm characteristics as controls: log of assets, leverage, stock volatility and ROA). The high yield dummy is equal to 1 if the stock issuing financial firm is rated as speculative. Ratings and issue size are obtained from S\&P's Capital IQ. Market capital is measured as the market price of the firm's stock one month prior to the stock issue announcement (obtained from CRSP) times the number of shares of common stock outstanding. Assets is the book value of the firm's assets at quarter end before the stock issue announcement. Leverage is total debt divided by total assets at quarter end before the stock issue announcement. ROA is annualized net income divided by total assets at quarter end before the stock issue announcement. Volatility is the standard deviation in the firm's stock prices in the quarter prior to the stock issue announcement. All balance sheet data are obtained from Call Reports and/or SEC 10-Q filings. Panel A presents results based on the split using the collapse of Bear Stearns (3/24/2008) to delineate the beginning of the crisis period, and panel B reports numbers based on the split using the TARP announcement (10/14/2008) to delineate the beginning of the crisis period. Robust standard errors are in parentheses.

Panel A - Crisis period starts with Bear Stearns acquisition by J.P. Morgan

Pre-crisis period: 01/01/2002-03/25/2008

Dependent Variable

Cumulative abnormal CDS spread

Cumulative abnormal stock return

(1)

(2)

(3)

(4)

(5)

(6)

\begin{tabular}{|c|c|c|c|c|c|c|}
\hline Constant & $\begin{array}{l}-1.794 \\
(1.107)\end{array}$ & $\begin{array}{c}-14.628 * \\
(2.181)\end{array}$ & $\begin{array}{c}-19.985^{*} \\
(2.838)\end{array}$ & $\begin{array}{l}-1.007 \\
(1.040)\end{array}$ & $\begin{array}{c}17.106 * * * \\
(0.036)\end{array}$ & $\begin{array}{c}18.880 * * \\
(0.464)\end{array}$ \\
\hline High yield dummy & $\begin{array}{c}-20.951 * * \\
(1.107)\end{array}$ & $\begin{array}{c}-23.438 * * \\
(0.783)\end{array}$ & $\begin{array}{c}-22.610^{* *} \\
(0.976)\end{array}$ & $\begin{array}{l}7.246^{*} \\
(1.040)\end{array}$ & $\begin{array}{c}20.519 * * \\
(0.980)\end{array}$ & $\begin{array}{c}20.245 * * \\
(1.096)\end{array}$ \\
\hline Issue size as \% of market cap & & & $\begin{array}{l}0.027 * \\
(0.003)\end{array}$ & & & $\begin{array}{l}-0.009 \\
(0.002)\end{array}$ \\
\hline $\begin{array}{l}\text { Control for asset size, leverage, } \\
\text { ROA and volatility }\end{array}$ & NO & YES & YES & NO & YES & YES \\
\hline Observations & 54 & 53 & 53 & 54 & 53 & 53 \\
\hline R-squared & $4.4 \%$ & $9.9 \%$ & $9.1 \%$ & $3.0 \%$ & $30.3 \%$ & $30.1 \%$ \\
\hline
\end{tabular}

Crisis period: 03/25/2008 -01/20/2011

Dependent Variable Cumulative abnormal CDS spread

Cumulative abnormal stock return

(1)

(2)

(3)

(4)

(5)

\begin{tabular}{|c|c|c|c|c|c|c|}
\hline Constant & $\begin{array}{l}-10.223 \\
(2.485)\end{array}$ & $\begin{array}{c}-185.276^{*} \\
(14.742)\end{array}$ & $\begin{array}{r}-156.639 \\
(58.429)\end{array}$ & $\begin{array}{l}-2.296 \\
(0.516)\end{array}$ & $\begin{array}{c}4.136 \\
(23.321)\end{array}$ & $\begin{array}{c}-0.009 \\
(32.895)\end{array}$ \\
\hline High yield dummy & $\begin{array}{c}-38.549 * * \\
(2.485)\end{array}$ & $\begin{array}{l}17.358 \\
(8.662)\end{array}$ & $\begin{array}{l}20.519 \\
(8.734)\end{array}$ & $\begin{array}{c}1.933 \\
(0.516)\end{array}$ & $\begin{array}{l}-1.478 \\
(0.711)\end{array}$ & $\begin{array}{l}-1.935 \\
(1.057)\end{array}$ \\
\hline Issue size as \% of market cap & & & $\begin{array}{l}-0.407 \\
(0.572)\end{array}$ & & & $\begin{array}{l}0.059 \\
(0.127)\end{array}$ \\
\hline $\begin{array}{l}\text { Control for asset size, leverage, } \\
\text { ROA and volatility }\end{array}$ & NO & YES & YES & NO & YES & YES \\
\hline Observations & 69 & 67 & 67 & 69 & 67 & 67 \\
\hline R-squared & $4.7 \%$ & $12.0 \%$ & $12.5 \%$ & $-1.4 \%$ & $-5.1 \%$ & $-3.6 \%$ \\
\hline
\end{tabular}


Panel B - Crisis period starts with TARP CPP announcement

Pre-crisis period: 01/01/2002 - 10/14/2008

Dependent Variable Cumulative abnormal CDS spread

(1)

(2)

(3)

$-1.547$

(1.134)

$-21.197 * *$

(1.134)

$-3.312 *$

$(0.442)$

$-34.680 * *$

(0.766)

Issue size as \% of market cap

High yield dummy

Control for asset size, leverage, ROA and volatility

Observations

R-squared

Crisis period: 10/14/2008-01/20/2011

NO

64

$3.5 \%$
Dependent Variable

(1)

Cumulative abnormal CDS spread

(2)

-12.250
$(5.760)$

$-187.774 * *$

$-158.956$

(4.063)

$-36.522 *$

(5.760)

20.019

(8.993)

Issue size as \% of market cap

Control for asset size, leverage, ROA and volatility

Observations

R-squared

$$
* * * \mathrm{p}<0.01, * * \mathrm{p}<0.05, * \mathrm{p}<0.1
$$

(11.340)

$-0.600$

(0.946)
Cumulative abnormal stock return

(4)

(5)

(6)

$\begin{array}{ccc}-1.586 & 13.423 * & 15.244 * \\ (0.816) & (1.196) & (1.382) \\ 7.826 * & 15.512 * * * & 15.281 * * * \\ (0.816) & (0.171) & (0.195) \\ & & -0.010 * \\ & & (0.001)\end{array}$

NO YES YES

$64 \quad 62 \quad 62$

$2.2 \%$

$16.2 \%$

$15.8 \%$

Cumulative abnormal stock return

(4)

(5)

(6)

$\begin{array}{lll}-1.826 * & -6.895 & -7.996\end{array}$

(0.161) (17.856) (25.014)

$1.464 * \quad-3.394 \quad-3.490 * *$

$\begin{array}{lll}(0.161) & (0.683) & (0.140)\end{array}$

0.023

(0.147)

\begin{tabular}{cccccc} 
NO & YES & YES & NO & YES & YES \\
\hline 59 & 58 & 58 & 59 & 58 & 58 \\
$3.9 \%$ & $8.7 \%$ & $9.7 \%$ & $-1.8 \%$ & $6.1 \%$ & $4.6 \%$ \\
\hline
\end{tabular}




\section{Table 7}

\section{Cross-sectional regression analysis of changes in the S\&P expected default frequency around a stock issue announcement to firm and issuance characteristics}

This table presents cross-sectional regressions of the change in the S\&P expected default frequency (EDF) around a stock issue announcement by a financial firm on firm and issuance characteristics. Specifically, we regress the change in the EDF for the issuing firm for 1-year, 2year, and 3-year horizons beginning from the quarter before the stock issue announcement on a risk measure-a dummy for being speculative-grade rated-a normalized issuance size measure (using market cap), and a set of firm characteristics as controls: log of assets, leverage, stock volatility and ROA). The high yield dummy is equal to 1 if the stock issuing financial firm is rated as speculative. Ratings and issue size are obtained from S\&P's Capital IQ. Market capital is measured as the market price of the firm's stock one month prior to the stock issue announcement (obtained from CRSP) times the number of shares of common stock outstanding. Assets is the book value of the firm's assets at quarter end before the stock issue announcement. Leverage is total debt divided by total assets at quarter end before the stock issue announcement. ROA is annualized net income divided by total assets at quarter end before the stock issue announcement. Volatility is the standard deviation in the firm's stock prices in the quarter prior to the stock issue announcement. All balance sheet data are obtained from Call Reports and/or SEC 10-Q filings. Standard errors are clustered by bank. Robust standard errors are in parentheses.

\begin{tabular}{lccc}
\hline & 1-yr horizon & 2-yr horizon & 3-yr horizon \\
\hline Constant & 69.342 & 69.297 & 61.769 \\
High Yield Dummy & $(44.866)$ & $(41.732)$ & $(37.949)$ \\
& $-23.402^{*}$ & $-22.581^{*}$ & $-21.296^{*}$ \\
Issuance Size as \% of Market Cap & $(12.440)$ & $(11.775)$ & $(10.947)$ \\
Controls for Asset Size, Leverage, ROA & $-0.079^{* *}$ & $-0.066^{* *}$ & $-0.063^{* *}$ \\
and Volatility & $(0.030)$ & $(0.027)$ & $(0.024)$ \\
\hline Observations & YES & YES & YES \\
R-squared & 82 & 82 & 82 \\
\hline
\end{tabular}

$* * * \mathrm{p}<0.01, * * \mathrm{p}<0.05, * \mathrm{p}<0.10$ 


\section{Figure 1}

\section{Distribution of Tier 1 Risk Based Capital Gap}

This figure shows the empirical distribution of the Tier 1 capital gap for 39 bank equity issuances during the sample period. The Tier 1 gap is calculated as the difference between the financial firm's Tier 1 risk-based capital ratio the quarter before the equity issue announcement and the FDIC benchmark of $6 \%$ required to be classified as a well-capitalized institution. A negative Tier 1 gap means that the institution's Tier 1 capital ratio falls below that threshold.

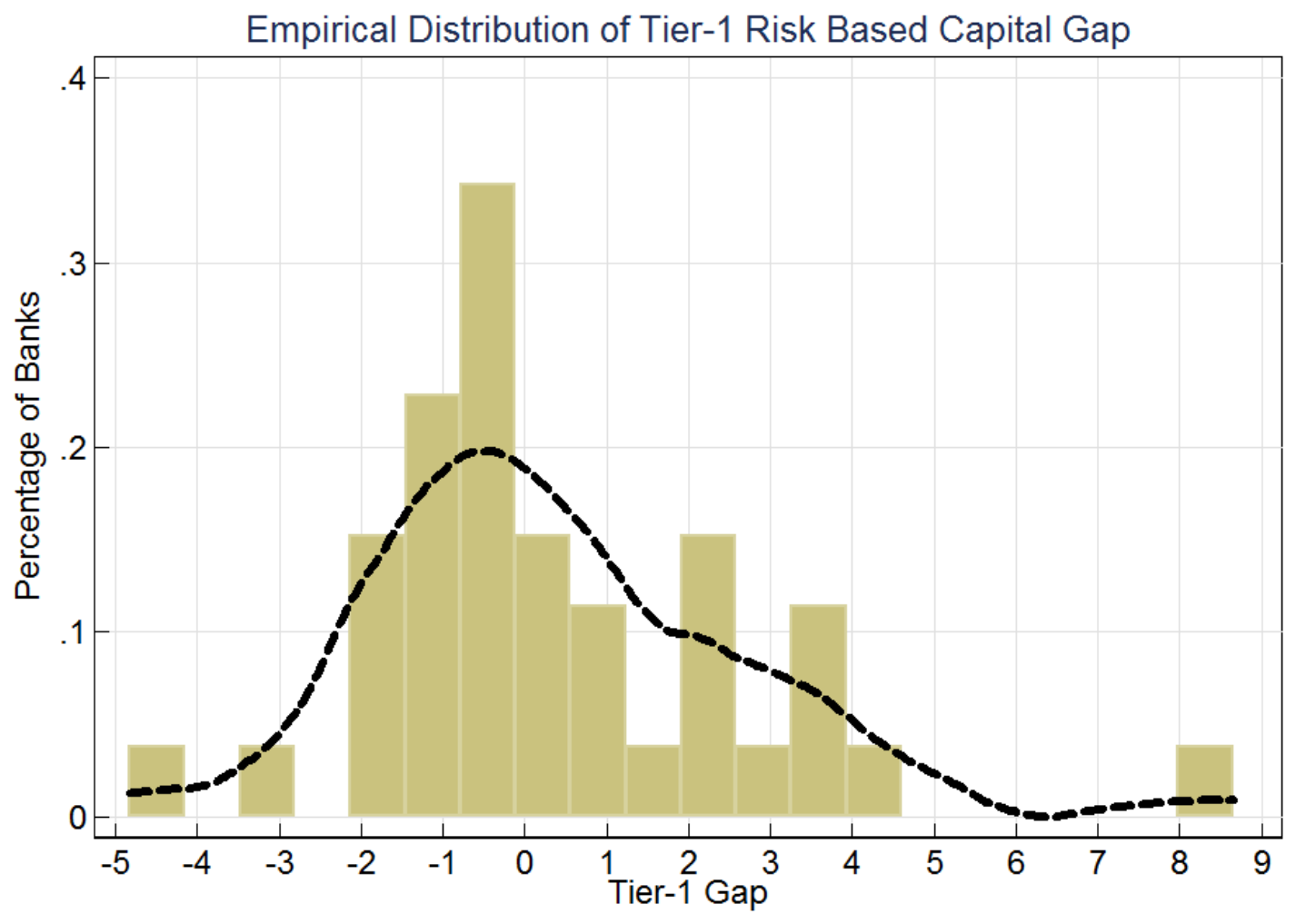




\section{Figure 2}

\section{CDS Mean Spreads for the Sample Banks in the 2002-2013 Period}

This figure plots the daily series of the mean CDS spreads of the 56 financial institutions that announced equity issuances between 2002 and 2013. This sample is collected from S\&P's Capital IQ database. We then limit the sample to those financial firms having CDS pricing data reported by Markit. The firm provides CDS end-of-day quotes for the CDS contracts

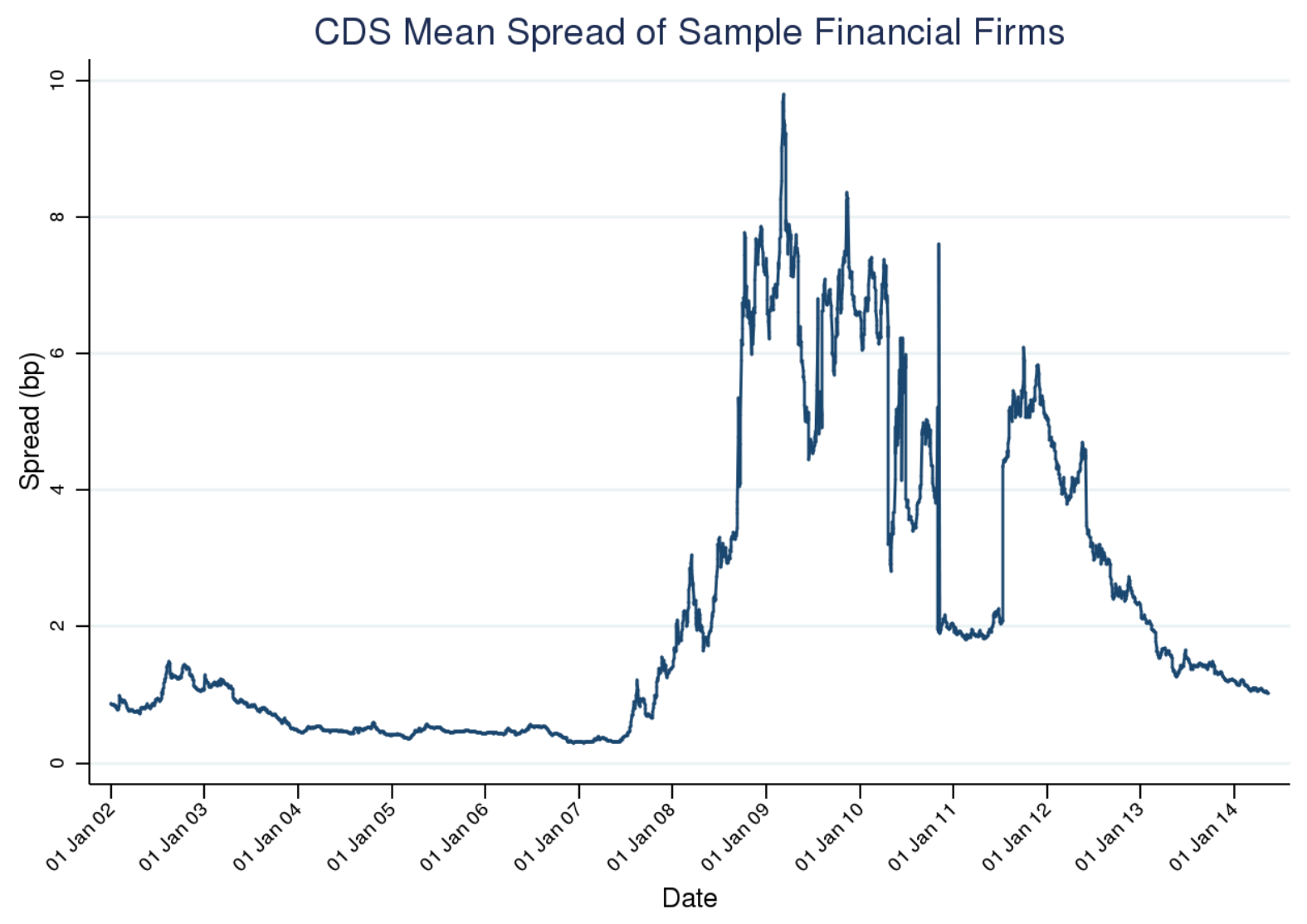




\section{Figure 3}

\section{Aggregate Market Equity Capitalization for the Sample Banks in the period 2002-2013}

This figure plots the daily evolution of the combined equity market capitalization of the 56 financial institutions that announced equity issuances between 2002 and 2013. Equity market capitalization is calculated as the daily stock price times the number of shares of common stock outstanding (from CRSP data tapes).

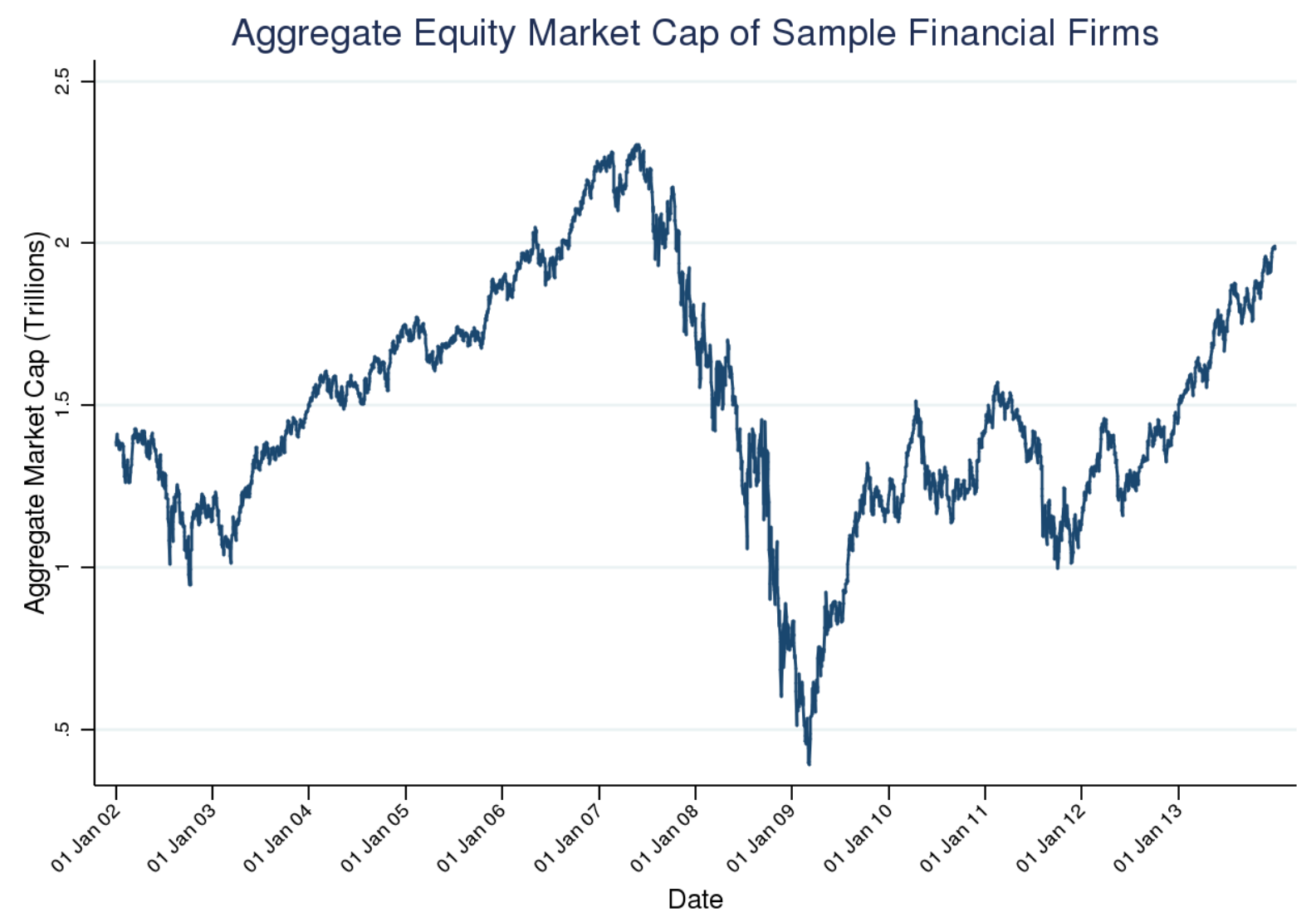




\section{References}

Alexopoulou, I., Andersson M, Georgescu, O.M., 2009. An empirical study on the decoupling movements between corporate bond and CDS spreads. European Central Bank, Working Paper No. 1085.

Andenmatten, S., Brill, F., 2011. Measuring co-movements of CDS premia during the Greek debt crisis, Discussion paper 11-04, Department of Economics, University of Bern.

Arce, O., Mayordomo, S., Pena, J.I., 2012. Credit-risk valuation in the sovereign CDS and bonds Markets: Evidence from the Euro area crisis, available at SSRN: http://ssrn.com/abstract=1896297.

Ballester, L., Casu, B., Gonzalez-Urteaga, A., 2013. Bank fragility and contagion: Evidence from the CDS market, Working paper University of Valencia.

Cornett, M.M., Lei, L., Tehranian, H., 2013. The performance of banks around the receipt and repayment of TARP funds. Journal of Banking and Finance 37, 730-746.

Cornett, M.M., Mehran, H., Tehranian, H., 1998. Are financial markets overly optimistic about the prospects of firms that issue equity? Evidence from voluntary versus involuntary equity issuances by banks. Journal of Finance 53, 2139-2160.

De Bruyckere, V., Gerhardt, M., Schepens, G., Vennet, R.V., 2013 Bank/sovereign risk spillovers in the European debt crisis. Journal of Banking and Finance 37, 4793-4809.

Di Cesare, A., Guazzarotti, G., 2010. An analysis of the determinants of credit default swap spread changes before and during the subprime financial turmoil, available at SSRN: http://ssrn.com/abstract=1670045.

Demirguc-Kunt, A., Huizinga, H., 2010. Are banks too big to fail or too big to save? International evidence from equity prices and CDS spreads. SSRN Working paper: http://ssrn.com/abstract=1626132.

Eichengreen, B., Mody, A., Nedeljkovic, M., Sarno, L., 2009. How the subprime crisis went global: Evidence from bank credit default swap spreads, NBER Working Paper No. 14904.

Flannery, M.J., Houston, J.F., Partnoy, F., 2010. Credit default swap spreads as viable substitutes for credit ratings. University of Pennsylvania Law Review 158(7), 2085-2123.

Fontana, A., Scheicher, M., 2010. An analysis of Euro area sovereign CDS and their relation with government bonds, available at SSRN: http://ssrn.com/abstract=1715483.

Galil, K., Shapir, O.M., Amiram, D., Ben-Zion, U., 2014. The determinants of CDS spreads. Journal of Banking and Finance 41, 271-282. 
Hull, J., Predescu, M., White, A., 2004. The relationship between credit default swap spreads, bond yields, and credit rating announcements. Journal of Banking and Finance 28, 27892811.

Ismailescu, I., Kazemi, H, 2010. The reaction of emerging market credit default swap spreads to sovereign credit rating changes. Journal of Banking and Finance 34, 2861-2873.

Jorion, P., Zhang, G., 2007. Good and bad credit contagion: Evidence from credit default swaps. Journal of Financial Economics 84, 860-883.

Kallestrup, R., Lando, D., Murgoci, A., 2012. Financial sector linkages and the dynamics of bank and sovereign credit spreads, available at SSRN: http://ssrn.com/abstract=2023635.

Mehran, H., Thakor, A., 2011. Bank capital and value in the cross-section. Review of Financial Studies 24, 1019-1067.

Miller, M., 1995. Do the M\&M propositions apply to banks? Journal of Banking and Finance 19, 483-489.

Ng, J., Vasvari, F.P., Wittenberg-Moerman, R., 2011. The impact of TARP's capital purchase program on stock market valuation of participating banks. SSRN Working paper: http://ssrn.com/abstract=1566284.

Norden, L., Weber, M., 2009. The co-movement of credit default swap, bond and stock markets: An empirical analysis. European Financial Management 15, 529-562.

Ross, S.A., 1977. The determination of financial structure: The incentive-signaling approach. Bell Journal of Economics 8, 23-40.

Veronesi, P., Zingales, L., 2010. Paulson's gift. Journal of Financial Economics 97, 339-368. 